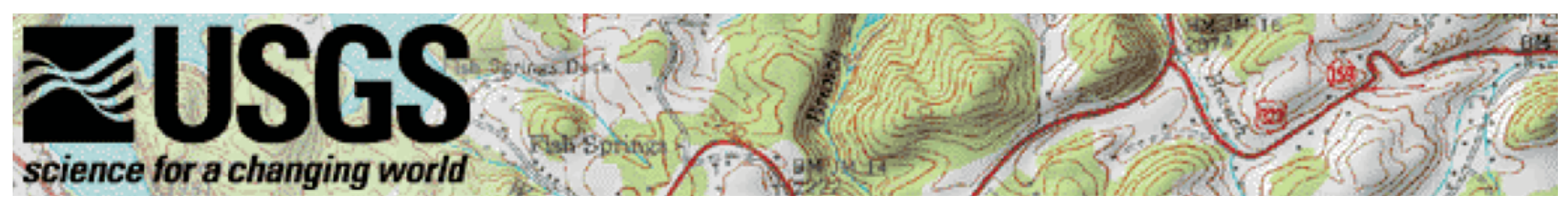

\title{
The National Map - Florida Pilot Project
}

\section{The Nation Needs The National Map}

Governments depend on a common set of geographic base information as a tool for economic and community development, land and natural resource management, and health and safety services. Emergency management and defense operations rely on this information. Private industry, nongovernmental organizations, and individual citizens use the same geographic data. Geographic information underpins an increasingly large part of the Nation's economy.

Available geographic data often have the following problems:

They do not align with each other because layers are frequently created or revised separately,

They do not match across administrative boundaries because each producing organization uses different methods and standards, and

They are not up to date because of the complexity and cost of revision.

The U.S. Geological Survey (USGS) is developing The National Map to be a seamless, continuously maintained, and nationally consistent set of online, public domain, geographic base information to address these issues. The National Map will serve as a foundation for integrating, sharing, and using other data easily and consistently.

In collaboration with other government agencies, the private sector, academia, and volunteer groups, the USGS will coordinate, integrate, and, where needed, produce and maintain base geographic data.

The National Map will include digital orthorectified imagery; elevation data; vector data for hydrography, transportation, boundary, and structure features; geographic names; and land cover information. The data will be the source of revised paper topographic maps.

Many technical and institutional issues must be resolved as The National Map is implemented. To begin the refinement of this new paradigm, pilot projects are being designed to identify and investigate these issues. The pilots are the foundation upon which future partnerships for data sharing and maintenance will be built.

\section{The Proposed Florida Pilot Project}

The USGS and the Southwest Florida Water Management District (SWFWMD) have proposed the Florida pilot project to support The National Map and the SWFWMD Comprehensive Watershed Management Initiative. The pilot could

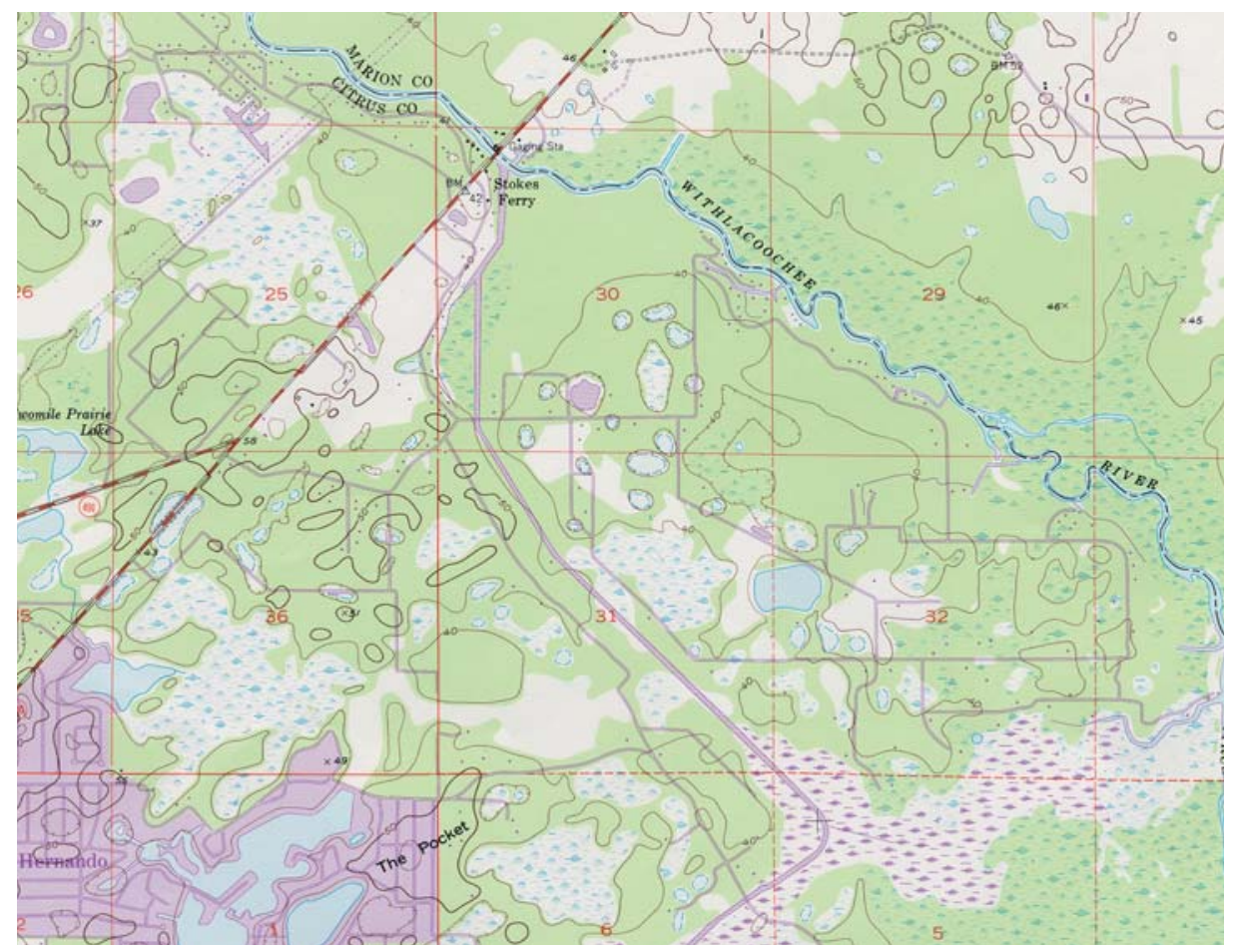

Withlacoochee River Watershed include other Federal and State partners. During the course of the proposed of Engineers, U.S. Environmental Protection Agency, USGS-Water Resources Discipline, National Oceanic and Atmospheric Administration, U.S. Fish and Wildlife Service, and Natural Resources Conservation Service, as well as State interests of the Department of Environmental Protection (FDEP), Bureau of State Lands, and Florida State University (FSU), will be addressed. Through partnership participation, this proposed pilot project can provide comprehensive support to the State and Federal sectors, while achieving the goals of The National Map for current, consistent, and accurate base geographic information.

The Watershed Management Initiative covers the Withlacoochee River watershed and its adjacent coastal waters. project, interests of the U.S. Army Corps 
This area has experienced a rapid growth in population, water demand, recreation, and other environmental stresses over the past 20 years. As in many areas of the State of Florida, incoming population is attracted to opportunities that require high quality, perennial water sources for housing, employment, and recreation. Rapid urbanization of the Greater Tampa Metropolitan Area has resulted in conflicting water use requirements that affect service delivery, environmental conservation, recreation, logging, and mining interests in the watershed and adjacent areas.

The SWFWMD, in cooperation with Federal, State, and local partners, will build a comprehensive, seamless geospatial database for the Withlacoochee River watershed and its coastal waters that will include orthoimagery, land cover/land characterization, elevation, hydrography, and geographic names data. Other data additions will be determined as partners are identified and cooperative arrangements are effected. The geospatial database will serve as a model and data source for implementation of The National Map in Florida.

In addition to the data collection and maintenance issues included under this proposed pilot project, the storage and dissemination of data resulting from this project would include services from FSU. The Bureau of State Lands, FDEP, and FSU will expand and enhance the existing capabilities of the Land Boundary Information System in this effort.

The USGS and the SWFWMD will cooperate with Federal, State, and academic partners to identify data stewards for each data category, establish clear lines of communication with data users, and identify database administrator responsibilities, as well as develop appropriate tools and procedures for

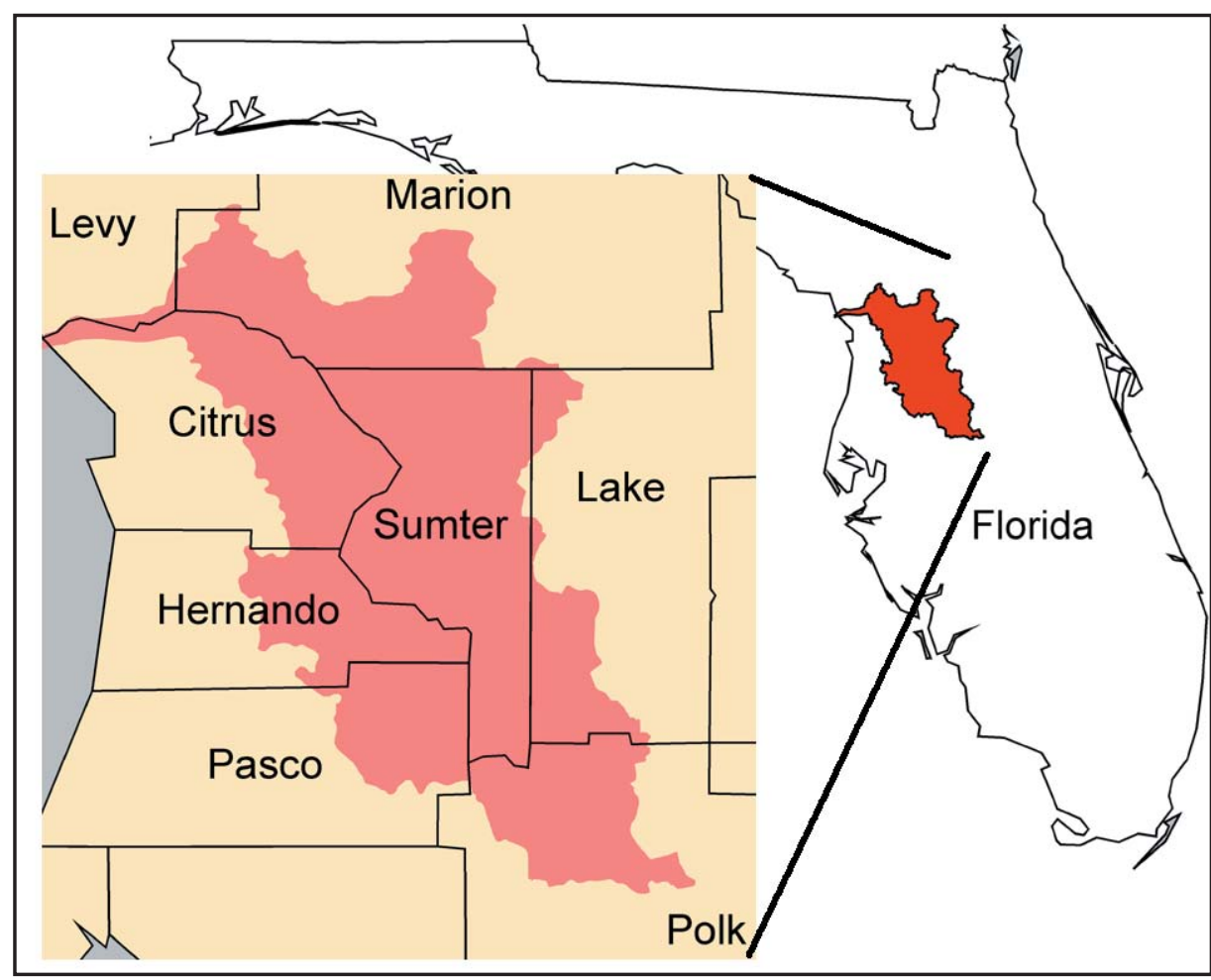

Florida Pilot Project Area

processing transactional updates for long-term maintenance of these data.

\section{More Information About the Proposed Florida Pilot Project}

\section{Dr. Steven Dicks}

Mapping and GIS Manager

Southwest Florida Water Management

District

2379 Broad Street

Brooksville, Fl 34604-6899

Phone: 352-796-7211 ext. 4200

E-mail: steve.dicks@swfwmd.state.fl.us

Or

G. Michael Callahan

U.S. Geological Survey

P.O. Box 710

Summerfield, FL 34491

Phone: 352-245-6193

E-mail: mcallaha@usgs.gov

\section{More Information About The National Map}

We welcome your comments on The National Map mission and strategies. You can view and download the full report at nationalmap.usgs.gov. Please share your thoughts about the vision with the USGS by e-mail at nationalmap@usgs.gov or by mail to USGS-National Map, MS 511 National Center, 12201 Sunrise Valley Drive, Reston, VA 20192. 